\title{
Dissolved free amino acids in the Sargasso Sea: uptake and respiration rates, turnover times, and concentrations
}

\author{
Curtis A. Suttle ${ }^{1}$, Amy M. Chan ${ }^{1}$, Jed A. Fuhrman ${ }^{2}$ \\ ${ }^{1}$ Marine Science Institute, The University of Texas at Austin, PO Box 1267, Port Aransas, Texas 78373-1267, USA \\ ${ }^{2}$ Department of Biological Sciences, University of Southern California, Los Angeles, California 90089-0371, USA
}

\begin{abstract}
Clean' techniques and high specific activity tritiated substrates were used to examine bacteria growth rates and uptake kinetics, and estimate turnover times and maximum concentrations $\left(K_{s}+S\right)$ of several dissolved free amino acids (DFAAs) in oligotrophic oceanic waters near Bermuda. Additions of a few nanomolar or less of a particular amino acid was generally but not always sufficient to generate uptake rates consistent with saturation-type kinetics. The proportion of label respired was generally 60 to $80 \%$ of the tritium taken up for glutamate, glutamine, alanine, glycine, serine and glucose. For leucine and ornithine $<10 \%$ of the tritium taken up was respired. The percentage of label respired was not dependent on the $C: N$ ratio of the substrate or the DFAA concentration, over the range that we examined. Although there are a number of explanations for the high percentage of label respired, one possibility is that high $\mathrm{C}: \mathrm{N}$ ratio substrates were supporting bacterial growth. If so, bacteria may not have been serving as $N$ remineralizers in this system. There were significant differences in turnover times of individual DFAAs with alanine being shortest (3.6 to $13.2 \mathrm{~h})$ and ornithine being longest ( 48 to $182 \mathrm{~h}$ ). Maximum concentration estimates of DFAAs were in the low-and sub-nM range whether determined from uptake kinetics data or by HPLC. From the turnover times and concentration estimates, we calculated the flux into particulate matter for each of the amino acids studied. Tentative calculations indicate that individual DFAAs could supply as much as $20 \%$ of the C and $N$ required to support bacterial growth. Our results indicate that although DFAA pools are small they are rapidly recycled and could be significant sources of $\mathrm{C}$ and $\mathrm{N}$ for bacterial growth in the Sargasso Sea
\end{abstract}

\section{INTRODUCTION}

For all planktonic systems bacterial production averages about $20 \%$ of the primary production (Cole et al. 1988). Assuming that aquatic bacteria on average have a $50 \%$ carbon-based growth efficiency, they would consume ca $40 \%$ of the carbon fixed by phytoplankton. This requires a proportionately large flux of dissolved organic matter (DOM) from the primary producers to the heterotrophs either directly via phytoplankton exudation (e.g. Mague et al. 1980) or indirectly through zooplankton grazing (e.g. Jumars et al. 1989). Yet we know very little about the chemical nature or the dynamics of the pools mediating these transfers in the open ocean.

Information from other systems indicates that dissolved free amino acids (DFAAs) represent a small but very labile fraction of the total DOM in seawater, and can supply a significant portion of the total bacterial requirements for C and $\mathrm{N}$ (Billen \& Fontigny 1987.
Fuhrman 1987). In some instances stimulation of bacterial growth by the addition of DFAAs cannot be explained simply as a requirement for nitrogen and carbon (Kirchman 1990). Dispite the apparent importance of DFAAs in supporting bacterial production there have been few systematic attempts to define the rate processes associated with DFAA cycling in oligotrophic oceanic environments. The purpose of this study was to obtain estimates of concentrations and turnover times for a variety of amino acids in the Sargasso Sea, with the objective of determining if DFAAs might be important $C$ and $N$ sources for bacterial growth in oligotrophic oceanic waters.

\section{MATERIALS AND METHODS}

Uptake experiments. Samples for amino acid uptake experiments were collected during August and November 1987 and July 1988, generally in the Sargasso 
Sea southeast of Bermuda. Experiments were done aboard ship and analyzed the same day or the next day at the Bermuda Biological Station. The location of the sampling stations varied depending on the weather, the vessel used, and the number of casts that needed to be done and are given in Table 1. They were generally located in $>300 \mathrm{~m}$ and often in $>1000 \mathrm{~m}$ of water along a transect between the northeast tip of Bermuda and Hydrostation $S\left(32^{\circ} 10^{\prime} \mathrm{N}\right.$, $64^{\circ} 30^{\prime} \mathrm{W}$ ). Water for experiments was collected from between 5 and $20 \mathrm{~m}$ (generally $10 \mathrm{~m}$ ) using an acidrinsed Go-Flo bottle (General Oceanics, Miami) which was suspended from a stainless-steel hydrowire, except for the August 1987 samples where a synthetic (Kevlar) wire was used.

Water $(40 \mathrm{ml})$ was drawn directly from the nipple of the Go-Flo bottle into clean, all-polypropylene $50 \mathrm{ml}$ syringes (Sigma) that had been rinsed 3 times each

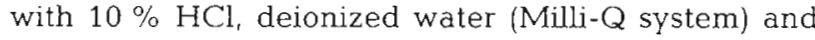
sample water from the Go-Flo. The night prior to use, aliquots of ${ }^{3} \mathrm{H}$-labelled DFAAs were placed into clean microfuge tubes and lyophilized to remove any ${ }^{3} \mathrm{H}$ water. Immediately before use each DFAA was redissolved in gently $0.2 \mu \mathrm{m}$-filtered seawater, prepared as described below for the HPLC samples. Approximately geometrically increasing quantities $i<100 \mu \mathrm{l}$ maximum volume) of high specific activity ( $\mathrm{TBq} \mathrm{mmol}^{-1}$ ) tritiated amino acids were immediately introduced through the nipples of 5 to 10 filled, nonreplicated syringes using an adjustable micropipettor, to achieve concentration ranges of 0.1 to a few nM. During the August 1987 sampling dates 5 duplicated concentrations were typically used. Formalin-killed controls were run in parallel on several occasions to confirm that the uptake of amino acids and the production of ${ }^{3} \mathrm{H}$-water were the result of biological activity. The total radioactivity in replicate $1 \mathrm{ml}$ subsamples was determined so that the concentrations added could be corrected for any errors caused by inaccurate pipetting of small volumes. The specific activities of the amino acids (purchased from NEN) were assumed to be as stated by the manufacturers. Fuhrman \& Ferguson (1986) found higher concentrations of DFAAs than expected from specific activity data supplied by the manufacturer, which would cause uptake rates to be underestimated if not corrected for Four of the amino acid stocks (leucine, glutamine, alanine and glycine) that we used during the 1988 experiments were checked for contamination and found to be similar or less than the stated concentrations. After addition of the isotope a small air bubble was temporarily introduced into each syringe to facilitate mixing. Incubations were started within about 20 min of collecting the water and were kept under low levels of indirect sunlight at ambient temperature. Incubations were kept as short as practicable (30 to $40 \mathrm{~min}$ ) to minimize container effects. The syringes were found to be convenient, non-contaminating incubation vessels that yielded good replication between syringes, and which were easily and accurately sampled.

Immediately following addition of the isotope and at the termination of experiments (30 to $40 \mathrm{~min}$ ) $10 \mathrm{ml}$ aliquots of sample were displaced from each syringe and filtered at a vacuum not exceeding $120 \mathrm{mmHg}$ through $0.2 \mu \mathrm{m}$ polycarbonate filters (Nuclepore), which were overlaid on Whatman GF/C glass-fiber filters. The polycarbonate filters were peeled off of the glass-fiber filters while maintaining the vacuum, alleviating the need for rinsing and resulting in consistent and low polycarbonate-filter blanks. Filtrates were trapped in scintillation vials and immediately frozen for later determination of respiration rates. The production of tritiated water over the course of the incubation was determined by vacuum distillation of frozen filtrates and counting the radioactivity in a known volume of the condensate. Formalin-killed controls were treated in a similar manner and were found not to accumulate tritium either as particulate matter or as water. Uptake rates were calculated by multiplying the concentration of the amino acid added by the proportion of the total radioactivity added that was taken up into particulate matter and (unless otherwise indicated) respired, over the incubation. This assumes an ambient concentration of zero and yields the most conservative estimate of uptake rate. This will result in an underestimate of the uptake rate that will be most pronounced at the lowest substrate additions. An exception to this was for calculations of the percent daily $\mathrm{C}$ and $\mathrm{N}$ requirements of bacteria that could be supplied by individual amino acids. For these data incorporation rates were calculated from uptake-rate constants, not corrected for respiration, and from the minimum determined pool sizes of the individual DFAAs.

The amino acids chosen for these experiments fit one or more of the following criteria: (1) they are representative of those which are typically most abundant in seawater (glutamate, glycine, alanine, serine); (2) they are important in the nitrogen-assimilation pathway of bacteria and phytoplankton (glutamate, glutamine); (3) they are important in the synthesis of specific cellular constituents such as proteins and polyamines (leucine, ornithine). In addition, uptake of glucose $\left(\mathrm{D}-\left[1-{ }^{3} \mathrm{H}\right]\right)$ was determined on several occasions. The amino acids were labelled as follows: glutamate, L- $\left[3,4-{ }^{3} \mathrm{H}\right]$; glutamine, L- $\left[3,4-{ }^{3} \mathrm{H}(\mathrm{N})\right]$; alanine, L- $\left[3-{ }^{3} \mathrm{H}\right]$; glycine, L$\left[2{ }^{3} \mathrm{H}\right]$; serine, $\mathrm{L}-\left[{ }^{3} \mathrm{H}(\mathrm{G})\right]_{i}$ ornithine, $\mathrm{L}-\left[2,3-{ }^{3} \mathrm{H}\right]_{\text {i leucine, }}$ $\mathrm{L}-\left[3,4,5-{ }^{3} \mathrm{H}(\mathrm{N})\right]$.

Bacterial growth rates were estimated from incorporation of tritiated thymidine into material insoluble in cold trichloroacetic acid (Fuhrman \& Azam 1982) using a 
conversion factor of $4 \times 10^{18}$ cells $\mathrm{mol}^{-1}$ of thymidine incorporated (Ducklow \& Hill 1985). These were converted into carbon and nitrogen demands assuming $20 \mathrm{fg}$ $\mathrm{C}$ and $5.6 \mathrm{fg} \mathrm{N}$ per bacterium (Lee \& Fuhrman 1987).

Calculation of kinetic parameters. Maximum estimates of ambient amino acid concentrations were calculated using a kinetics approach (Parsons \& Strickland 1962, Wright \& Hobbie 1966). If the relationship between uptake rate and concentration is described by a rectangular hyperbola then it is possible to obtain a maximum estimate of the ambient nutrient concentration using a modification of the Michaelis-Menten formulation for enzyme kinetics. The form of the relationship is $V=V_{\max }(S+A)\left(K_{s}+S+A\right)^{-1}$ where $V$ is the uptake rate, $V_{\max }$ is the nutrient-saturated uptake rate, $S$ is the ambient nutrient concentration, $A$ is the concentration of nutrient added, and $K_{S}$ is the concentration at which $V=0.5\left(V_{\max }\right)$. As $A$ is known, and $V$ and $V_{\max }$ can be estimated from rates of isotope incorporation, it is possible to calculate $K_{s}+S$, which provides similar estimates of ambient amino acid concentrations to those determined by HPLC (Jørgensen \& Sondergaard 1984, Cole \& Lee 1986, Fuhrman \& Ferguson 1986). It should be pointed out that estimates of $K_{s}+S$ will not be affected by respiration, if the proportion of label respired does not vary over the range of substrate concentrations used. Consequently, we did not include respiration in the uptake rates used to estimate $K_{s}+S$, thus eliminating one source of error in our estimates of DFAA concentrations.

Least-squares nonlinear regression analysis (Currie 1982, Li 1983j and distribution-free direct linear plotting techniques (Eisenthal \& Cornish-Bowden 1974) provide the most accurate estimates of parameters from experiments displaying saturation kinetics. In the direct-linear plot method each nutrient concentration added and its associated $V$ defines a line in the $K_{s}+S$ versus $V_{\max }$ plane (Fig. 1). The number of points where these lines intersect is $0.5 n(n-1)$ where $n$ is the number of substrate concentrations added. Each intersection gives an independent estimate of $V_{\max }$ and $K_{s}$; the median value of each parameter gives the best estimate. The fit of the uptake data to the MichaelisMenten relationship was tested using unweighted nonlinear least-squares regression as recommended by $\mathrm{Li}$ (1983). Where the data were adequately described $\left(\mathrm{r}^{2}\right.$ $\geq 0.85$ ), kinetic parameters were estimated both by least-squares regression using the Quasi-Newtonian estimation procedure in SYSTAT (SYSTAT, Inc.), and by direct linear plots using a computer program written in BASIC (Brady \& Ishizaki 1989). Confidence intervals for parameter estimates calculated by least-squares regression were provided by SYSTAT. Methods for establishing confidence intervals and handling replicate observations using direct-linear plotting are

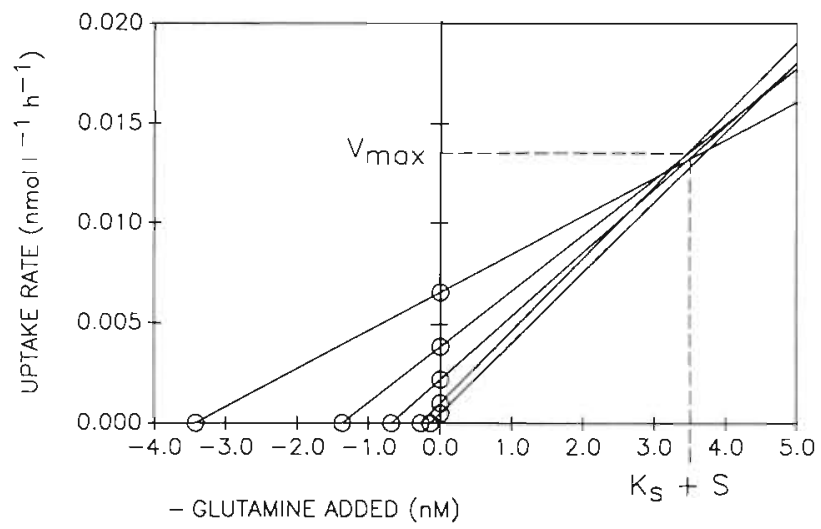

Fig. 1. Direct-linear plot of glutamine uptake on 4 November 1987 illustrating the determination of $K_{s}+S$ and $V_{\max }$ from data described by Michaelis-Menten-type uptake kinetics. The negative value of each amino acid concentration added is plotted on the $x$-axis and joined by a line to its associated uptake rate plotted on the $y$-axis. The intersection of each line gives an independent estimate of $K_{s}+S$ and $V_{\max }$ and the median value of these estimates provides the most accurate determination of $K_{s}+S$ and $V_{\max }$

described in Porter \& Trager (1977). Parameter estimates are only given for data for which the Michaelis-Menten model yielded least-squares-regression $r^{2}$ values of 0.85 or greater (20 of 25 experiments). Turnover times of DFAA pools were estimated from the uptake rates at the 2 lowest substrate concentrations added, except for the August 1987 data where the duplicates from the lowest substrate addition were used. Turnover times were corrected for respiration.

Samples for determination of DFAA concentrations by HPLC were frozen immediately after collection and transferred back to the laboratory on frozen $\mathrm{CO}_{2}$. The samples were kept frozen and analyzed 1 mo later using pre-column o-phthaldialdehyde (OPA) derivatization as outlined by Fuhrman \& Bell (1985). Unfiltered samples were collected directly from the nipple of the Go-Flo bottle into ashed, acid-washed glass scintillation vials that were rinsed 5 times with sample, and with caps lined with acid-washed and sample-rinsed Teflon cap liners. For filtered samples an acid-washed Sterifil system (Millipore Corp.) containing a $47 \mathrm{~mm}$ diameter, $0.2 \mu \mathrm{m}$ polycarbonate filter was rinsed with copious amounts of sample water and filled with $200 \mathrm{ml}$ of Sargasso Sea water. Under extremely gentle vacuum (just enough so some water flow was observed) three $30 \mathrm{ml}$ samples were filtered into the bottom of a Sterifil unit and used to rinse the container before a fourth sample was collected and an aliquot placed into a clean scintillation vial.

\section{RESULTS}

The observed kinetics were generally adequately described by the Michaelis-Menten formula (Fig. 1, Table 1) and the uptake of trace additions of labelled 


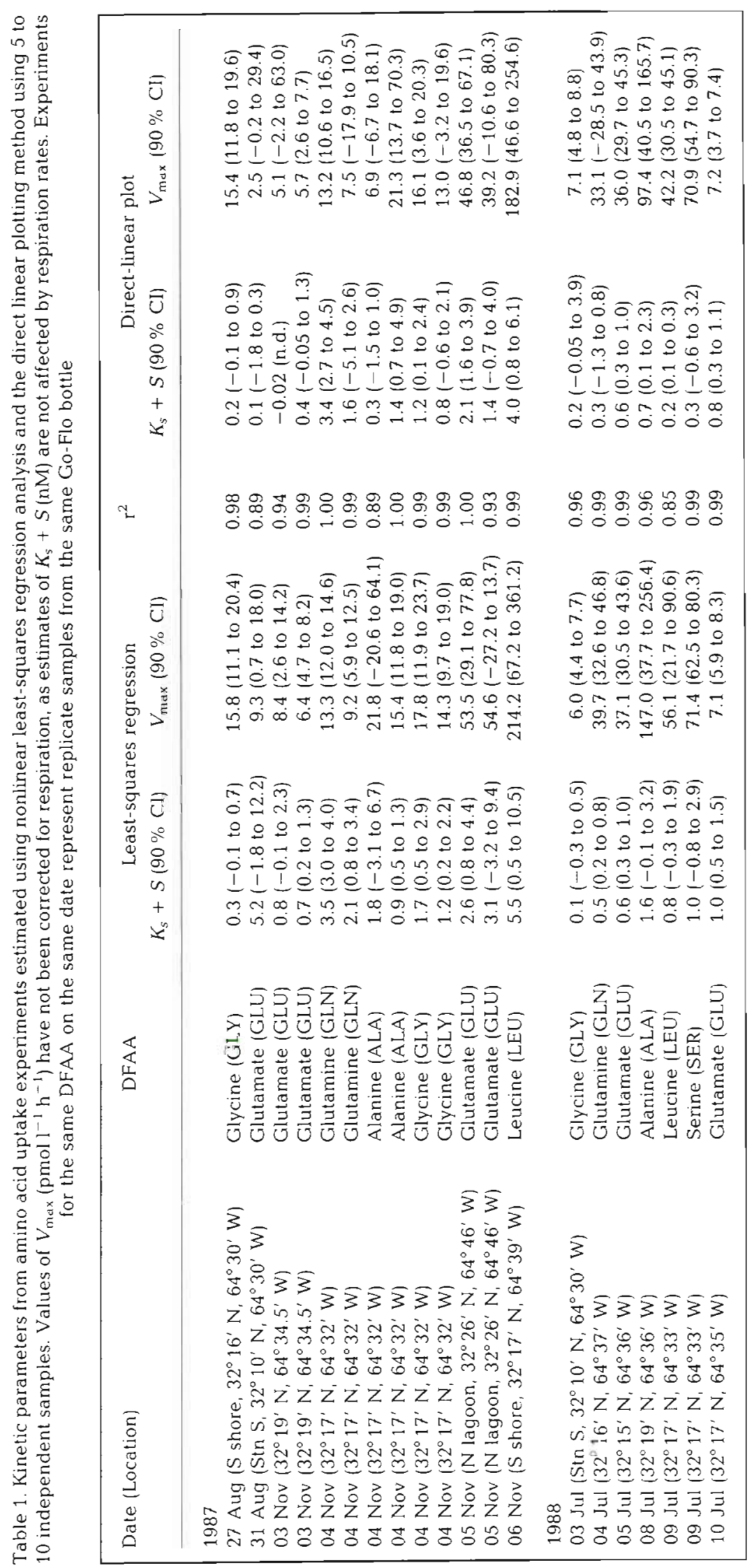




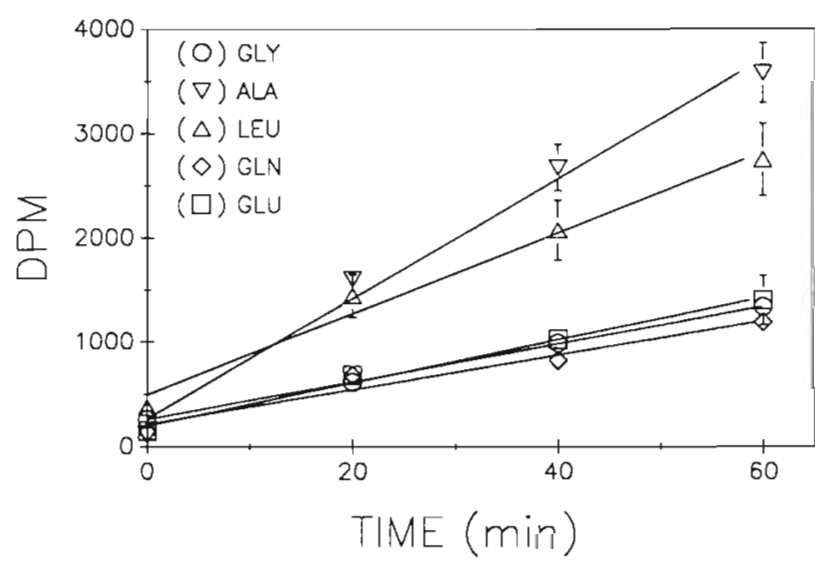

Fig. 2. Time course of uptake of trace additions (ca $0.1 \mathrm{nM}$ ) of tritiated amino acids into $>0.2 \mu \mathrm{m}$ size fraction. Where error bars are not shown the standard deviation of duplicate determinations was less than the width of the symbols. Lines were fitted by linear regression

substrates did not deviate significantly from linearity $\left(\mathrm{r}^{2}=0.95\right.$ to 1.00$)$ over incubation periods of up to 60 min (Fig. 2). Estimates of $K_{s}+S$ and $V_{\max }$ were affected by the procedure used to estimate them. The direct-linear plot method yielded significantly lower values (Wilcoxon signed ranks tests) for both $K_{s}+S$ $(\mathrm{p}=0.001)$ and $V_{\max }(\mathrm{p}=0.002)$ than did least-squares regression. Nonetheless, both methods provided estimates of $K_{\mathrm{s}}+S$ for individual amino acids in the range of $<1 \mathrm{nM}$ to a few nM (Table 1, Fig. 3). In 5 instances the kinetics data were not well described by the Michaelis-Menten formulation $\left(\mathrm{r}^{2}<0.85\right)$ and are not included in Table 1.

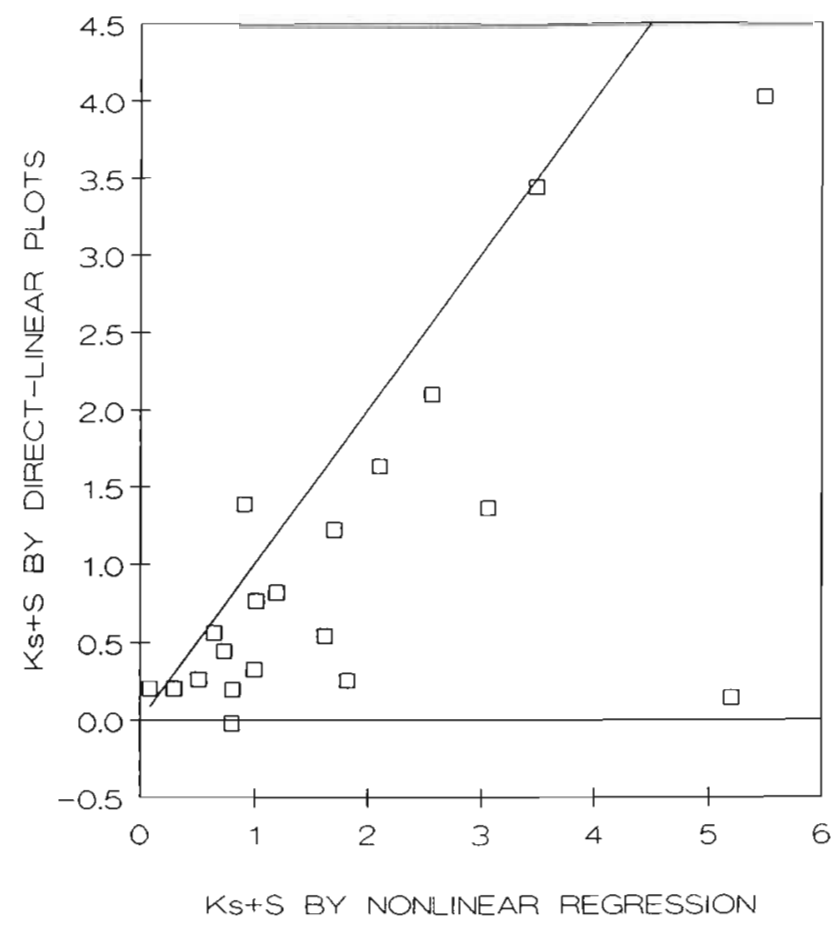

Fig. 3. Comparison of $K_{s}+S(\mathrm{nM})$ determined by nonlinear least-squares regression analysis and by the direct-linear plotting method for the pooled 1987 and 1988 amino acid uptake data. The line represents a relationship of $1: 1$

Where amino acid concentrations were also determined by HPLC (July 1988), the values were in the same range as those determined by the kinetics method (Tables 1 \& 2). The most abundant amino acids in terms of concentration and their relative contribution

Table 2. DFAA concentrations (nM) determined by HPLC for amino acids which were also used in uptake experiments. Percentage of total DFAA concentration (molarity) made up of individual amino acids is indicated in parentheses. It should be noted that the ornithine and lysine peaks were not eluted from the column and were therefore not included in the total DFAA measurement. Samples from the same date were taken from the same Go-Flo bottle. Position on $6 \mathrm{July} 1988$ was $32^{\circ} 10^{\prime} \mathrm{N}$, $64^{\circ} 34^{\prime} \mathrm{W}$; other positions are as in Table 1

\begin{tabular}{|llccccccc}
\hline Date, time (1988) & Treatment & GLU & SER & GLN/HIS & GLY & ALA & LEU & Total \\
\hline 03 Jul 14:30 h & Filtered & Trace & $2.1(33.5)$ & Trace & $1.9(30.3)$ & $0.9(14.4)$ & $0.1(1.6)$ & 6.3 \\
03 Jul 14:30 h & Filtered & Trace & $1.4(23.1)$ & Trace & $1.8(29.9)$ & $0.7(12.1)$ & $0.2(2.8)$ & 6.1 \\
03 Jul 14:30 h & Unfiltered & $0.1(1.4)$ & $1.4(17.2)$ & $0.3(3.2)$ & $1.9(23.3)$ & $1.0(11.7)$ & $0.1(1.5)$ & 8.1 \\
04 Jul 14:30 h & Filtered & $0.2(1.3)$ & $3.1(21.7)$ & $0.3(1.7)$ & $3.5(24.1)$ & $1.4(9.8)$ & $0.3(2.1)$ & 14.3 \\
04 Jul 14:30 h & Filtered & $0.2(1.0)$ & $2.9(15.7)$ & $0.2(1.3)$ & $3.7(19.9)$ & $1.6(8.5)$ & $1.5(8.0)$ & 18.4 \\
04 Jul 14:30 h & Unfiltered & $0.1(1.2)$ & $0.5(6.5)$ & $0.3(4.1)$ & $1.3(17.4)$ & $0.7(9.9)$ & $0.1(0.9)$ & 7.4 \\
05 Jul 10:00 h & Filtered & Trace & $0.7(20.2)$ & Trace & $1.1(31.5)$ & $0.5(14.5)$ & Trace & 3.4 \\
06 Jul 15:30 h & Filtered & $0.3(1.4)$ & $5.3(25.2)$ & $0.4(1.8)$ & $5.9(28.1)$ & $3.2(15.0)$ & $0.5(2.1)$ & 21.1 \\
06 Jul 15:30 h & Filtered & Trace & $1.6(18.2)$ & $0.1(1.3)$ & $2.7(31.1)$ & $1.1(12.7)$ & $0.2(1.8)$ & 8.7 \\
06 Jul 15:30 h & Unfiltered & $0.4(1.3)$ & $6.8(20.3)$ & $1.1(3.3)$ & $8.0(23.6)$ & $4.9(14.5)$ & $0.6(1.9)$ & 33.7 \\
09 Jul 11:00 h & Filtered & Trace & $3.2(22.9)$ & $0.4(2.8)$ & $3.6(26.3)$ & $1.4(10.4)$ & $0.4(2.5)$ & 13.8 \\
10 Jul 13:45 h & Filtered & $1.6(2.8)$ & $10.5(18.8)$ & $1.6(2.9)$ & $11.0(19.7)$ & $5.6(10.0)$ & $1.7(3.0)$ & 55.9 \\
10 Jul 13:45 h & Filtered & $1.5(3.0)$ & $10.7(20.9)$ & $1.2(2.2)$ & $10.7(20.7)$ & $5.7(11.0)$ & $1.6(3.0)$ & 51.5 \\
10 Jul 13:45 h & Unfiltered & $0.3(1.6)$ & $4.5(23.3)$ & $0.5(2.8)$ & $4.8(25.1)$ & $2.2(11.2)$ & $0.4(2.0)$ & 19.2 \\
\hline
\end{tabular}


Table 3. Averages, standard deviations (SD) and number of experiments ( $n$ ) for the turnover time of individual DFAA pools and the percent of ${ }^{3} \mathrm{H}$ respired during experiments in 1987 and 1988

\begin{tabular}{|c|c|c|c|c|c|c|c|c|c|c|c|c|}
\hline \multirow[t]{3}{*}{ Compound } & \multicolumn{6}{|c|}{ Turnover time (h) } & \multicolumn{6}{|c|}{$\%$ Uptake respired } \\
\hline & \multicolumn{3}{|c|}{1987} & \multicolumn{3}{|c|}{1988} & \multicolumn{3}{|c|}{1987} & \multicolumn{3}{|c|}{1988} \\
\hline & Mean & $\mathrm{SD}$ & $\mathrm{n}$ & Mean & $\mathrm{SD}$ & $n$ & Mean & $\mathrm{SD}$ & $\mathrm{n}$ & Mean & $\mathrm{SD}$ & n \\
\hline GLU & 22.0 & 6.8 & 4 & 19.6 & 14.5 & 3 & 78.1 & 6.2 & 6 & 61.6 & 10.9 & 14 \\
\hline GLN & 50.9 & 22.7 & 4 & 25.3 & 16.7 & 3 & 65.9 & 7.4 & 5 & 67.6 & 14.0 & 8 \\
\hline ALA & 6.9 & 5.3 & 4 & 8.3 & 4.9 & 2 & 77.3 & 12.8 & 6 & 75.8 & 4.3 & 7 \\
\hline GLY & 10.4 & 4.3 & 4 & 10.0 & - & 1 & 82.2 & 3.7 & 6 & 83.7 & 3.8 & 4 \\
\hline LEU & 22.2 & - & 1 & 11.7 & 5.8 & 2 & 4.6 & 7.0 & 4 & 2.2 & 8.7 & 5 \\
\hline ORN & 48.7 & 0.0 & 2 & 144.2 & 37.7 & 2 & 3.2 & 4.6 & 2 & -7.9 & - & 1 \\
\hline SER & - & - & - & 15.5 & 1.1 & 2 & - & - & - & 65.1 & 11.6 & 5 \\
\hline Glucose & - & - & - & 39.7 & 23.2 & 8 & - & - & - & 59.8 & 15.9 & 9 \\
\hline
\end{tabular}

to the total DFAA pool (\% total molarity) were glycine, serine and alanine, which occurred at low nM levels. The lowest concentrations measured by HPLC for each of the 6 sampling dates were assumed to be the least contaminated and most closely reflect ambient concentrations, but the variation between some replicates suggests an unknown potential source of contamination so even the lowest values could be overestimates. The lowest concentrations measured for each sampling date for glycine, serine and alanine ranged from 1.1 to $4.8 \mathrm{nM}, 0.5$ to $4.5 \mathrm{nM}$ and 0.5 to $2.2 \mathrm{nM}$, respectively. The $K_{s}+S$ estimates for these amino acids tended to be lower and were $0.2 \mathrm{nM}, 0.3 \mathrm{nM}$ and $0.7 \mathrm{nM}$, respectively, during July 1988. Glutamate, glutamine-histidine and leucine comprised only a few percent of the total DFAA pool and HPLC-determined concentrations were consistently sub-nM and occasionally undetectable. The $K_{S}+S$ estimates for these amino acids were also sub-nM. The lowest daily estimates of the total DFAA pool sizes for July 1988 ranged from 3.4 to $19.2 \mathrm{nM}$. The samples were not run long enough to elute ornithine or lysine peaks from the column so the contribution of these to the total DFAAs is unknown.

In uptake experiments using glutamate, glutamine, alanine, glycine and serine, typically 60 to $80 \%$ of the ${ }^{3} \mathrm{H}$ label was respired as water (Table 3 ). A somewhat less and more variable amount of the glucose label was respired, while little label was respired during leucineand ornithine-uptake experiments. Over the restricted range of concentrations that we used ( 0 to $5 \mathrm{nM}$ ) we were unable to detect any effect of concentration on the proportion of label respired (Fig. 4).

Respiration-corrected turnover times (Table 3) for the individual amino acids were typically on the order of tens of hours, but were on occasion only a few hours. Exceptions were the ornithine turnover times in 1988 which were $>100 \mathrm{~h}$. Both in 1987 and 1988 there were significant differences in turnover times between amino acids (ANOVA, $p<0.01$ ). In both years alanine had the shortest average turnover time while ornithine

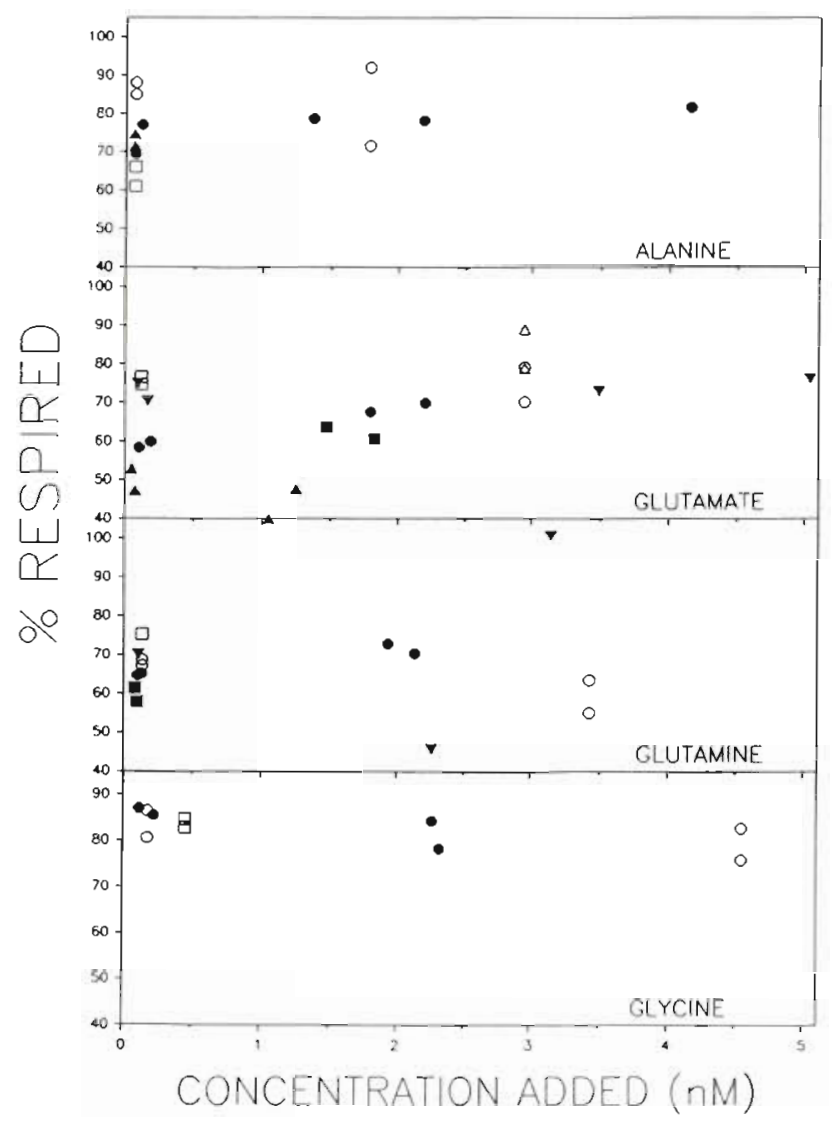

Fig. 4. Percent of ${ }^{3} \mathrm{H}$ respired over a range of amino acid concentrations. Data for a given amino acid were taken from several experiments indicated by different symbols. Alanine: (0) 4 Nov 1987, (=) 5 Nov 1987, (4) 5 Jul 1988, (•) 8 Jul 1988; glutamate: (0) 3 Nov 1987, (4) 5 Nov 1987 - Expt 1, () 5 Nov 1987

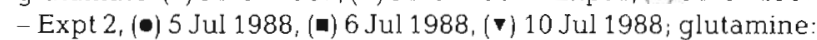
(o) 4 Nov 1987, (c) 5 Nov 1987, (•) 4 Jul 1988, (•) 5 Jul 1988, (v) 6 Jul 1988; glycine: (o) 4 Nov 1987, (口) 5 Nov 1987, (•) 3 Jul 1988

and glutamine had the longest. In 1987 the turnover times fell into 3 groups (ALA, GLY, GLU) (GLY, GLU, ORN) (ORN, GLN) while in 1988 there were only 2 groups (ALA, LEU, SER, GLU, GLN) (ORN). The mean turnover times of the DFAAs within each of the above 
Table 4. Estimates of the proportion of $C$ and $N$ supplied by individual DFAAs relative to the demand required (ng $l^{-1} \mathrm{~d}^{-1}$ ) to sustain growth rates $\left(\mathrm{d}^{-1}\right)$ calculated from rates of ${ }^{3} \mathrm{H}$ thymidine incorporation. $\mathrm{C}$ and $\mathrm{N}$ uptake rates $\left(\mathrm{ng} \mathrm{l}^{-1} \mathrm{~d}^{-1}\right)$ at ambient DFAA concentrations were determined from the uptake-rate constants (not corrected for respiration) for trace additions of amino acids and from the minimum DFAA pool sizes (as determined either chemically or kinetically). Estimated ambient DFAA concentrations are shown in parentheses

\begin{tabular}{|c|c|c|c|c|c|c|c|c|c|}
\hline Date & $\begin{array}{l}\text { DFAA } \\
\text { (nM) }\end{array}$ & $\begin{array}{l}\text { Upt } \\
\text { C }\end{array}$ & $\begin{array}{r}\text { ake } \\
\text { N }\end{array}$ & $\begin{array}{l}\text { Cell no. } \\
\left(\times 10^{6}\right)\end{array}$ & Growth & $\begin{array}{c}C \\
\text { demand }\end{array}$ & $\stackrel{\mathrm{N}}{\text { demand }}$ & $\begin{array}{c}\% \\
\text { daily C }\end{array}$ & $\begin{array}{c}\% \\
\text { daily } N\end{array}$ \\
\hline \multicolumn{10}{|l|}{1987} \\
\hline $03 \mathrm{Nov}$ & GLU $(0.8)$ & 17.7 & 4.1 & 0.60 & 0.07 & 78 & 22 & 22.6 & 18.7 \\
\hline 03 Nov & GLU (0.4) & 5.5 & 1.3 & 0.60 & 0.07 & 78 & 22 & 7.0 & 5.8 \\
\hline 04 Nov & GLN (3.4) & 17.5 & 8.2 & 0.62 & 0.11 & 131 & 36 & 13.3 & 22.6 \\
\hline $04 \mathrm{Nov}$ & GLN (1.6) & 9.2 & 4.3 & 0.62 & 0.11 & 131 & 36 & 7.0 & 11.9 \\
\hline 04 Nov & ALA (0.3) & 4.6 & 1.8 & 0.62 & 0.11 & 131 & 36 & 3.5 & 5.0 \\
\hline 04 Nov & $\operatorname{ALA}(0.9)$ & 11.0 & 4.3 & 0.62 & 0.11 & 131 & 36 & 8.5 & 12.0 \\
\hline 04 Nov & GLY (1.2) & 8.2 & 4.8 & 0.62 & 0.11 & 131 & 36 & 6.3 & 13.3 \\
\hline $04 \mathrm{Nov}$ & GLY $(0.8)$ & 5.5 & 3.2 & 0.62 & 0.11 & 131 & 36 & 4.2 & 8.9 \\
\hline 05 Nov & GLU (2.1) & 63.9 & 14.9 & 0.45 & 0.27 & 239 & 66 & 26.8 & 22.6 \\
\hline 05 Nov & GLU (1.4) & 37.8 & 8.8 & 0.45 & 0.27 & 239 & 66 & 15.8 & 13.4 \\
\hline 06 Nov & $\operatorname{LEU}(4.0)$ & 288.6 & 56.1 & 0.60 & 0.12 & 139 & 38 & 207.6 & 147.6 \\
\hline \multicolumn{10}{|l|}{1988} \\
\hline $04 \mathrm{Jul}$ & $\operatorname{GLN}(0.2)$ & 21.5 & 10.0 & 1.21 & 0.20 & 485 & 136 & 4.4 & 7.4 \\
\hline 09 Jul & $\operatorname{LEU}(0.2)$ & 59.5 & 11.6 & 2.06 & 0.14 & 574 & 160 & 10.4 & 7.2 \\
\hline $09 \mathrm{Jul}$ & SER (0.3) & 18.7 & 7.3 & 2.06 & 0.14 & 574 & 160 & 3.3 & 4.6 \\
\hline $10 \mathrm{Jul}$ & GLU (0.3) & 4.0 & 0.9 & 1.76 & 0.09 & 272 & 76 & 1.5 & 1.2 \\
\hline
\end{tabular}

groups, within years, were not significantly different from each other (Tukey test, $p>0.05$ ).

Growth rates of bacteria (Table 4 ) ranged between 0.07 and $0.27 \mathrm{~d}^{-1}$ although the absolute accuracy of these values is unknown, because of the uncertainty associated with the thymidine conversion factor (Ducklow \& Hill 1985). These growth rates translate into $\mathrm{C}$ and $\mathrm{N}$ demands of 78 to $574 \mathrm{ng} \mathrm{Cl} \mathrm{Cl}^{-1} \mathrm{~d}^{-1}$ and 22 to $160 \mathrm{ng} \mathrm{N}$ $\mathrm{1}^{-1} \mathrm{~d}^{-1}$, respectively. The fraction of bacterial $\mathrm{C}$ and $\mathrm{N}$ requirements that was supplied by amino acids can be calculated from estimates of DFAA pool sizes and turnover times, and bacterial biomass and growth rates. Except for high values for leucine during November 1987, probably the result of an overestimate in concentration, estimates of the percentage of bacteria $\mathrm{C}$ and $\mathrm{N}$ requirements supplied by an individual amino acid ranged from 2 to $27 \%$ and 1 to $23 \%$, respectively. As the tritium was covalently bonded to $\mathrm{C}$ it should have been a better tracer of $C$ metabolism than $N$ metabolism. For this reason and as the error associated with several of the calculations is unknown, but potentially large, these results should be considered approximate.

\section{DISCUSSION}

\section{Determination of kinetic parameters}

The direct-linear plotting method gave significantly lower estimates of both $K_{s}+S$ (Fig. 3) and $V_{\max }$. Directlinear plots have rarely been used to estimate kinetic parameters in field experiments. However, estimates of $K_{s}$ from phosphate uptake experiments on natural communities of phytoplankton were higher and more variable when determined using a linearization of the Michaelis-Menten equation than when using directlinear plots (Suttle \& Harrison 1988).

The best method for the determination of kinetic parameters from nutrient uptake experiments is the subject of an extensive literature (e.g. Dowd \& Riggs 1965, Currie 1982, Li 1983) which cannot be reviewed here. However, it is generally recognized that linear transformations of the Michaelis-Menten equation provide the least satisfactory estimates of $V_{\max }$ and $K_{s}$, while least-squares non-linear regression analysis (Currie 1982, Li 1983) and distribution-free direct-linear plotting techniques (Eisenthal \& Cornish-Bowden 1974) provide the best estimates. However, regression assumes that values of $Y$ are normally distributed about $X$, and parameter estimates are particularly sensitive to outlying values of $Y$ at extreme values of $X$. In contrast, the direct-linear plotting method makes no underlying assumptions regarding distribution, and because the parameter estimates are based on median rather than mean values they are very insensitive to outliers. Intuitively, distribution-free estimates of $V_{\max }$ and $K_{s}$ should be most appropriate for data collected on field samples where the variance in estimates of $V$ are frequently unknown and may change as a result of the substrate concentrations added. Indeed, where the distribution and magnitude of the error in $V$ is unknown the directlinear plot is most accurate (Atkins \& Nimmo 1975). 


\section{Amino acid concentration}

As there are a number of significant problems in attempting to model uptake kinetics of a complex microbial assemblage using a Michaelis-Menten model (e.g. Williams 1973, Tarapchak \& Herche 1986) one must be cautious in interpreting $K_{s}+S$ estimates of amino acid concentration. Additionally, errors may occur because certain amino acids can compete for the same uptake site. For example, several pairs of DFAAs are mutually inhibitory to uptake in estuarine microorganisms, including threonine and serine, glycine and alanine, lysine and arginine, leucine and alanine, aspartate and glutamate, and aspartate and asparagine (Crawford et al. 1974). Consequently, a measured $K_{s}+$ $S$ could reflect the concentration of the added amino acid as well as other amino acids, although this is apparently only a problem when competing amino acids are present at high concentrations (Crawford et al. 1974). Furthermore, even extremely gentle filtration can disrupt flagellates and other delicate cells resulting in overestimates of kinetically or chemically determined DFAA concentrations (Fuhrman \& Bell 1985) As a number of artifacts can lead to overestimation of DFAA concentrations the values we report must be regarded as maximum-concentration estimates. Nevertheless, in carefully designed experiments estimates of amino acid concentrations from values of $K_{s}+S$ agree with chemical measurements (Jørgensen \& Sondergaard 1984, Cole \& Lee 1986, Fuhrman \& Ferguson 1986)

Our estimates for individual DFAA concentrations were in the low-nM or sub-nM range whether determined as $K_{s}+S$ or by HPLC (Tables $1 \& 2$ ). Many of the values are lower than previously reported for the Sargasso Sea (Liebezeit et al. 1980) and the Baltic (Mopper \& Lindroth 1982) but similar to those for the California Bight (Carlucci et al. 1984). Moreover, the total of individual amino acid concentrations for each of the July 1988 sampling dates (3.4 to 19.2 nMi Table 2) were comparable to other estimates for surface waters from the Sargasso Sea (Lee \& Bada 1977) and Gulf of Mexico (Ferguson \& Sunda 1984), although considerably less than reported for total OPA-reactive substances from the Sargasso (Liebezeit et al. 1980).

\section{Respiration and turnover}

Generally 60 to $80 \%$ of the label in uptake experiments using glutamate, glutamine, alanine, glycine, serine and glucose was respired (Table 3, Fig. 4). Reports for more coastal waters indicate that the percentage respired is typically 20 to $60 \%$ for both ${ }^{3} \mathrm{H}$ (Carlucci et al. 1984, 1986) and ${ }^{14} \mathrm{C}$-labelled amino acids (Crawford et al. 1974, Williams et al. 1976, Dawson \& Gocke 1978, Kellar et al. 1982, Palumbo et al. 1983, Coffin 1989), with values closer to 20 being more common for ${ }^{14} \mathrm{C}$-labelled DFAAs. By using short incubations there is the possibility that isotopic equilibrium of cellular pools was not reached (Billen et al. 1980, King \& Berman 1984). The observation that uptake proceeded linearly for $60 \mathrm{~min}$ and the high proportion of label that was respired argues against this (Fig. 2).

Less than $10 \%$ of the label in leucine-uptake experiments was respired, similar to the results of others for both ${ }^{3} \mathrm{H}$ - (Burnison \& Morita 1974) and ${ }^{14} \mathrm{C}$-labelled (Crawford et al. 1974, Williams et al. 1976, Kellar et al. 1982) leucine and isoleucine. Presumably because leucine is primarily directed into protein synthesis (Kirchman et al. 1985) it is inaccessible to respiratory pathways. Ornithine was also respired very little, in contrast to the results of others (Burnison \& Morita 1974, Jørgensen et al. 1983). Decarboxylation of ornithine to form putrescine is the major mechanism for the biosynthesis of the polyamines, spermidine and spermine (Moat \& Foster 1988), which are closely associated with DNA (Tabor \& Tabor 1984). If most of the ornithine uptake was directed into synthesis of polyamines this may be why there was little respiration of ornithine.

Despite the fact that uptake rates for individual amino acids were frequently saturated at concentrations of a few nM, over the limited range of concentrations employed the proportion of the amino acid uptake that was respired was independent of concentration (Fig. 4). This has also been found for ${ }^{14} \mathrm{C}$-labelled glucose (Azam \& Hodson 1981) and a variety of DFAAs (Crawford et al. 1974, Kirchman \& Hodson 1984, 1986, Carlucci et al. 1986) when added at a range of relatively low concentrations. The reason for this needs to be addressed by future studies. Potential explanations include that an induction period is required before metabolism can respond to increased substrate, that increases in DFAA concentration were so little relative to bacterial requirements for organic carbon that bacterial metabolism was unaffected, or that bacteria growth rates were limited by a nutrient other than carbon or nitrogen. Our results differ from those of others, however, in that the proportion of label respired was greater. Perhaps Sargasso Sea bacteria inherently have a lower growth efficiency or were growing at such low rates relative to their potential maximum that most substrate was required to fulfill respiratory demands.

An intriguing possibility is that the proportion of label respired was indicative of the $\mathrm{C} N$ ratio of the combined substrates that the bacteria were using for growth. In our experiments (with the exceptions of leucine and ornithine, see abovel the proportion of label respired was similar even though the $C: N$ ratios 
of the added substrates ranged widely. This is also true for most other studies where the proportion of uptake respired has been determined for trace additions of glucose and DFAAs. The trace additions employed in our experiments likely did not significantly alter the overall $C: N$ ratio of the pool of dissolved organic matter used by bacteria. Studies indicate that the carbon-based growth efficiency of marine bacteria depends on the $\mathrm{C}: \mathrm{N}$ ratio of the combined substrates, with a much greater proportion of carbon being respired when bacteria are growing on high C: N substrates (Goldman et al. 1987, Hopkinson et al. 1989). In fact, $60 \%$ of the carbon taken up was respired only when the overall $C: N$ ratio of the substrates was in excess of $10: 1$ (by atoms). If such laboratory results can be extrapolated to Sargasso Sea assemblages, then the high proportion of label respired (Table 3, Fig. 4) suggests that the bacteria were growing on substrates with a high combined $\mathrm{C}: \mathrm{N}$ ratio $(>10: 1)$. This assumes that ${ }^{3} \mathrm{H}$ (covalently bonded to $C$ ) was adequately tracing carbon. If bacteria in the Sargasso Sea were growing on C: N substrates $>10: 1$ then they may not have been significant regenerators of inorganic nitrogen. This is consistent with observations from several marine systems showing that bacteria take up ammonium (Wheeler \& Kirchman 1986, Fuhrman et al. 1988, Suttle et al. 1990), and provides further evidence that much of the regeneration of inorganic nitrogen results from consumption of phytoplankton and bacteria by predators (e.g. Sherr et al. 1983, Goldman et al. 1985). Until a better understanding is realized, arguments of what dictates the proportion of substrate lost to respiration will largely be conjecture.

We estimate that turnover times of individual DFAAs were on the order of hours (Table 3). These results imply tight coupling between release and uptake of DFAAs, as has been reported for other waters (Fuhrman 1987). The times are in the range reported for oligotrophic waters in the Gulf of Mexico (Ferguson \& Sunda 1984), but more rapid than most other determinations for the euphotic zone of the oligotrophic ocean (see summaries in Billen 1984, Ferguson \& Sunda 1984). Turnover times were not significantly different between years (ANOVA; $p>0.05$ ) and averages for individual DFAAs tended to be similar even though most of the 1987 samples were taken in November and the 1988 samples were collected in July. It is interesting that there were significant differences in the turnover times of individual amino acids with alanine having the shortest average turnover, and glutamine and ornithine the longest in both 1987 and 1988. The reason why alanine would have a shorter turnover time than glutamine is unknown. Both DFAAs have lower $\mathrm{C}: \mathrm{N}$ ratios $(3: 1$ and $5: 2$, respectively) than required for balanced growth by bacteria and estimates of concentration indicate that dissolved pools of glutamine were less than alanine.

\section{Ecological implications}

Estimated bacteria doubling times were relatively long ( 2.5 to $10 \mathrm{~d}$ ), yet the small pools of dissolved free amino acids cycled rapidly (Tables 1, 2 \& 3). Our calculations suggest that individual DFAAs supplied as much as $20 \%$ of the daily $\mathrm{C}$ and $\mathrm{N}$ requirements of bacteria (Table 4). The November data suggest that glutamate, glutamine, alanine and glycine together supplied 40 to $50 \%$ of the total bacterial requirements for $\mathrm{C}$ and $\mathrm{N}$. This assumes that ${ }^{3} \mathrm{H}$ was serving as an adequate tracer of $\mathrm{C}$ and $\mathrm{N}$ metabolism. Tritium probably traces $\mathrm{C}$ adequately because it is covalently bonded to $C_{\text {; }}$ however, it is less likely to be an accurate tracer of $\mathrm{N}$ metabolism. As $\mathrm{N}$ is not respired it is likely that the proportion of $\mathrm{N}$ incorporated would have been greater than that of $\mathrm{C}$, in which case DFAAs would supply a greater proportion of bacterial nitrogen requirements. For this reason and because the factor required to convert thymidine incorporation rate into growth rate is not well established for oceanic bacteria (Ducklow \& Hill 1985) the error associated with these estimates may be considerable. Nonetheless, the results suggest that amino acids fulfill a significant portion of the bacterial demand for $\mathrm{N}$ and $\mathrm{C}$, consistent with results from coastal waters (Billen \& Fontigny 1987, Fuhrman 1987) and eutrophic lakes (Jørgensen et al. 1983, Jørgensen 1987). Further, if the high proportion of ${ }^{3} \mathrm{H}$ respired is indicative of growth on combined substrates with an overall $\mathrm{C}: \mathrm{N}$ ratio $>10: 1$, this suggests that bacteria in the oligotrophic ocean may be inefficient remineralizers or even consumers of inorganic nitrogen.

It is clear that a large portion of carbon fixed by phytoplankton ultimately fuels bacterial production in the euphotic zone (Cole et al. 1988). Although the pathways that mediate the transfer of carbon and nitrogen between the primary producers and bacteria in the open ocean are complex, it is apparent that the fluxes of $\mathrm{C}$ and $\mathrm{N}$ through the dissolved free amino acid pools are a significant and integral component of this process.

Acknowledgements. This work was supported by grants from the National Science Foundation (OCE 8711132 and OCE 8996136). We thank Drs L. Proctor and S. Lee for their help on this project, and Drs F. Azam and J. C. Goldman for insightful discussions. Contribution No. 781 of the Marine Science Institute, University of Texas. Comments by Drs C. Lee, R. H. Benner and 2 anonymous reviewers improved the manuscript. 


\section{LITERATURE CITED}

Atkins, G. L., Nimmo I. A. (1975). A comparison of seven methods for fitting the Michaelis-Menten equation. Biochem. J. 149: 775-777

Azam, F., Hodson, R. E. (1981). Multiphasic kinetics for Dglucose uptake by assemblages of natural marine bacteria. Mar. Ecol. Prog. Ser. 6: 213-222

Billen, G. (1984). Heterotrophic utilization and regeneration of nitrogen. In: Hobbie, J. E., Williams, P. J. LeB. (eds.) Heterotrophic activity in the sea. Plenum Press, New York, p. 313-356

Billen, G., Claude, J., Wijnant, J., Gillain, G. (1980). Concentration and microbiological utilization of small organic molecules in the Scheldt Estuary, the Belgian coastal zone of the North Sea and the English Channel. Estuar. coast. mar. Sci. 11: 279-294

Billen, G., Fontigny, A. (1987). Dynamics of a Phaeocystisdominated spring bloom in Belgian coastal waters. II. Bacterioplankton dynamics. Mar. Ecol. Prog. Ser. 37: 249-257

Brady, J. F., Ishizaki, H. (1989). A BASIC programm for the estimation of Michaelis-Menten parameters by the direct linear plot. Comput. Meth. Prog. Biomed. 28: 271-272

Burnison, B. K., Morita, R. Y. (1974). Heterotrophic potential for amino acid uptake in a naturally eutrophic lake. Appl. Microbiol. 27: 488-495

Carlucci, A. F., Craven, D. B., Henrichs, S. M. (1984). Diel production and microheterotrophic utilization of dissolved free amino acids in waters off southern California. Appl. environ. Microbiol. 48: 165-170

Carlucci, A. F., Craven, D. B., Robertson, K. J., Henrichs, S. M. (1986). Microheterotrophic utilization of dissolved free amino acids in depth profiles of southern California borderland basin waters. Oceanologica Acta 9: 89-96

Coffin, R. B. (1989). Bacterial uptake of dissolved free and combined amino acids in estuarine waters. Limnol. Oceanogr. 34: 531-542

Cole, J. J., Findlay, S., Pace, M. L. (1988). Bacterial production in freshwater and saltwater ecosystems: a cross system overview. Mar. Ecol. Prog. Ser. 43: 1-10

Cole, J. J., Lee, C. (1986). Rapid microbial metabolism of nonprotein amino acids in the sea. Biogeochem. 2: 299-312

Crawford, C. C., Hobbie, J. E., Webb, K. L. (1974). The utilization of dissolved free amino acids by estuarine microorganisms. Ecology 55: 551-563

Currie, D. J. (1982). Estimating Michaelis-Menten parame ters: bias, variance and experimental design. Biometrics 38: $907-919$

Dawson, R., Gocke, K. (1978). Heterotrophic activity in comparison to the free amino acid concentrations in Baltic sea water samples. Oceanologica Acta 1: 45-54

Dowd, J. E., Riggs, D. S. (1965). A comparison of estimates of Michaelis-Menten kinetic constants from various linear transformations. J. biol. Chem. 240: 863-869

Ducklow, H. W., Hill, S. M. (1985). Tritiated thymidine incorporation and the growth of heterotrophic bacteria in warm core rings. Limnol. Oceanogr. 30: 260-272

Eisenthal, R., Cornish-Bowden, A (1974). The direct linear plot. A new graphical procedure for estimating enzyme kinetic parameters. Biochem. J. 139: 715-720

Ferguson, R. L., Sunda, W. G. (1984). Utilization of amino acids by planktonic marine bacteria: importance of clean techniques and low substrate additions. Limnol. Oceanogr. 29: $258-274$

Fuhrman, J. A. (1987). Close coupling between release and uptake of dissolved free amino acids in seawater studied by an isotope dilution approach. Mar. Ecol. Prog. Ser. 37: 45-52
Fuhrman, J. A., Azam F. (1982). Thymidine incorporation of heterotrophic bacterioplankton production in marine surface waters: evaluation and field results. Mar. Biol. 66: $109-120$

Fuhrman, J. A., Bell, T, M. (1985). Biological considerations in the measurement of dissolved free amino acids in seawater and implications for chemical and microbiological studies Mar. Ecol. Prog. Ser. 25: 13-21

Fuhrman, J. A., Ferguson, R. L. (1986). Nanomolar concentrations and rapid turnover of dissolved free amino acids in seawater: agreement between chemical and microbiological measurements. Mar. Ecol. Prog. Ser. 33: 237-242

Fuhrman, J. A., Horrigan, S. G., Capone, D. G. (1988). Use of ${ }^{13} \mathrm{~N}$ as a tracer for bacterial and algal uptake of ammonium seawater. Mar. Ecol. Prog. Ser. 45: 271-278

Goldman, J. C., Caron, D. A., Anderson, O. K., Dennett, M. R (1985). Nutrient cycling in a microflagellate foodchain: I Nitrogen dynamics. Mar. Ecol. Prog. Ser. 24: 231-242

Goldman, J. C., Caron, D. A., Dennett, M. R. (1987). Regulation of gross growth efficiency in bacteria by substrate C: N ratio. Limnol. Oceanogr. 32: 1239-1252

Hopkinson, C. S., Sherr, B., Wiebe, W. J. (1989). Size fractionated metabolism of coastal microbial plankton. Mar. Ecol Prog. Ser. 51: 155-166

Jørgensen, N. O. G. (1987). Free amino acids in lakes: concentrations and assimilation rates in relation to phytoplankton and bacterial production. Limnol. Oceanogr. 32: 97-111

Jørgensen, N. O. G., Sondergaard, M. (1984). Are dissolved free amino acids free? Microb. Ecol. 10: 301-316

Jørgensen, N. O. G., Sondergaard, M., Hansen, H. J., Bosselmann, S., Riemann, B. (1983). Diel variation in concentration, assimilation and respiration of dissolved free amino acids in relation to planktonic primary and secondary production in two eutrophic lakes. Hydrobiologia 107: 107-122

Jumars, P. A., Perry, D. L., Baross, J. A., Perry, M. J., Frost, B. W. (1989). Closing the microbial loop: dissolved carbon pathway to heterotrophic bacteria from incomplete ingestion, digestion and absorption in animals. Deep Sea Res. 36: 483-495

Kellar, M. D., Mague, T. H., Badenhausen, M., Glover, H. E. (1982). Seasonal variations in the production and consumption of amino acids by coastal microplankton. Estuar. coast. Shelf Sci. 15: 301-315

King, G. M., Berman, T (1984). Potential effects of isotopic dilution on apparent respiration in ${ }^{14} \mathrm{C}$ heterotrophy experiments. Mar. Ecol. Prog. Ser. 19: 175-180

Kirchman, D. (1990). Limitation of bacterial growth by dis solved organic matter in the subarctic Pacific. Mar. Ecol. Prog. Ser. 62: 47-54

Kirchman, D., Hodson, R. (1984). Inhibition by peptides of amino acid uptake by bacterial populations in natural waters: implications for the regulation of amino acid transport and incorporation. Appl. environ. Microbiol. 47: 624-631

Kirchman, D., Hodson, R. (1986). Metabolic regulation of amino acid uptake in marine waters. Limnol. Oceanogr. 31: $339-350$

Kirchman, D., K nees, E., Hodson, R. (1985). Leucine incorporation and its potential as a measure of protein synthesis by bacteria in natural aquatic systems. Appl. environ. Microbiol. 49: 599--607

Lee, C., Bada, J. L. (1977). Dissolved amino acids in the equatorial Pacific, the Sargasso Sea, and Biscayne Bay. Limnol. Oceanogr. 22: 502-510

Lee, S., Fuhrman, J. A. (1987). Relationships between biovolume and biomass of naturally derived marine bacterioplankton. Appl. environ. Microbiol. 53: 1298-1303 
Li, W. K. W. (1983). Consideration of errors in estimating kinetic parameters based on Michaelis-Menten formalism in microbial ecology. Limnol. Oceanogr. 28: 185-190

Liebezeit, G., Bolter, M., Brown, I. F., Dawson, R. (1980). Dissolved free amino acids and carbohydrates at pycnocline boundaries in the Sargasso Sea and related microbial activity. Oceanologica Acta 3: 357-362

Moat, A. G., Foster, J. W. (1988). Microbial physiology, 2nd edn. Wiley, New York

Mague, T H., Friberg, E., Hughes, D. J., Morris, I. (1980). Extracellular release of carbon by marine phytoplankton: a physiological approach. Limnol. Oceanogr 25: 262-279

Mopper, K., Lindroth, P. (1982). Diel and depth variations in dissolved free amino acids and ammonium in the Baltic Sea determined by shipboard HPLC analysis. Limnol. Oceanogr. 27: 336-347

Palumbo, A. V., Ferguson, R. L., Rublee, P. A. (1983). Efficient utilization of dissolved free amino acids by suspended marine bacteria. J. exp. mar. Biol. Ecol. 69: 257-266

Parsons, T. R., Strickland, J. D. H. (1962). On the production of particulate organic carbon by heterotrophic processes in sea water Deep Sea Res. 8: 211-222

Porter, W. R., Trager, W. F. (1977). Improved non-parametric statistical methods for the estimation of Michaelis-Menten kinetic parameters by the direct linear plot. Biochem. J. 161: 293-302

Sherr, B. F., Sherr, E. B., Berman, T. (1983). Grazing, growth, and ammonium excretion rates of a heterotrophic micro-

This article was presented by N. S. Fisher, Stony Brook, New York, USA flagellate fed with four species of bacteria. Appl. environ. Microbiol. 45: 1196-1201

Suttle, C. A., Fuhrman, J. A., Capone, D. G. (1990). Rapid ammonium cycling and concentration-dependent partitioning of ammonium and phosphate: implications for carbon transfer in planktonic communities. Limnol. Oceanogr. 35: 424-433

Suttle, C. A., Harrison, P. J. (1988). Ammonium and phosphate uptake kinetics of size-fractionated plankton from an oligotrophic freshwater lake. J. Plankton Res. 10: 133-149

Tabor, C. W., Tabor, H. (1984). Polyamines. Ann. Rev. Biochem. 53: 749-790

Tarapchak, S. J., Herche, L. R. (1986). Phosphate uptake by microorganisms in lake water: deviations from simple Michaelis-Menten kinetics. Can. J. Fish. Aquat. Sci. 43: 319-328

Wheeler, P. A., Kirchman, D. L. (1986). Utilization of inorganic and organic nitrogen by bacteria in marine systems. Limnol. Oceanogr. 31: 998-1009

Williams, P. J. LeB. (1973). The validity of the application of simple kinetic analysis to heterogeneous microbial populations. Limnol. Oceanogr. 18: 159-165

Williams, P. J. LeB., Berman, T., Holm-Hansen, O. (1976). Amino acid uptake and respiration by marine heterotrophs. Mar. Biol. 35: 41-47

Wright, R. T., Hobbie, J. E. (1966). Use of glucose and acetate by bacteria and algae in aquatic ecosystems. Ecology 47 : $447-464$

Manuscript first received: July 6, 1990

Revised version accepted: December 17, 1990 